\title{
The Implementation of MDGs Program on Eradication of Extreme Poverty and Hunger in Indonesia (2009-2014)
}

\author{
Syifa Zia Rahmah ${ }^{1}$, Grace Lestariana Wonoadi ${ }^{2}$, Achmad Zulfikar $^{3}$ \\ ${ }^{1}$ Faculty of Social and Political Sciences, Muhammadiyah Yogyakarta University, Indonesia, \\ syifazia1704@gmail.com \\ ${ }^{2}$ Faculty of Social and Political Sciences, Muhammadiyah Yogyakarta University, Indonesia, \\ grace_1w808@yahoo.com \\ ${ }^{3}$ Faculty of Social and Political Sciences, Hasanuddin University, Indonesia, \\ apa@kabarfikar.com
}

\begin{abstract}
The study of the implementation of Millenium Development Goals (MDGs) program in Indonesia aims to find out the background and significance of the program taken by the government under President Susilo Bambang Yudhoyono in 2009-2014 on the issue of eradication of extreme poverty and hunger. The problem of extreme poverty and hunger in Indonesia has not been solved comprehensively. Therefore, the government had to provide the right program to end poverty. The research will be based on the qualitative method, which uses official reports, literature and news articles as the sources. The result showed that the programs of eradication extreme poverty and hunger in 2009-2014 had been revised became three clusters. The first cluster aims to help and protects the social family guarantee and to assure the basic needs. The second cluster is the eradication of poverty and hunger through the social assistance program. The third cluster was focusing on eradication of poverty and hunger in term of economic matter. The government used the indicators by UNDP, as the base of the decision-making process, but also used the real condition of poor people in Indonesia as the main consideration.
\end{abstract}

Keywords: Millenium Development Goals, Extreme Poverty and Hunger

\begin{abstract}
ABSTRAK
Kajian mengenai program Millenium Development Goals (MDGs) di Indonesia bertujuan untuk mengetahui latar belakang dan signifikansi program yang diambil oleh pemerintah di bawah pemerintahan Presiden Susilo Bambang Yudhoyono pada tahun 2009-2014 tentang pemberantasan kemiskinan dan kelaparan ekstrim. Isu kemiskinan dan kelaparan ekstrim di Indonesia belum terpecahkan secara komprehensif. Oleh karena itu, pemerintah harus menyediakan program yang tepat untuk mengakhiri kemiskinan. Data yang digunakan oleh peneliti adalah sumber sekunder, yaitu penelitian kepustakaan seperti buku dan jurnal, dan rujukan dari internet. Hasil kajian menunjukkan bahwa program pemberantasan kemiskinan dan kelaparan di tahun 2009-2014 telah direvisi menjadi tiga kelompok. Kelompok pertama bertujuan untuk membantu dan melindungi keluarga melalui jaminan sosial dan untuk menjamin kebutuhan dasar. Kelompok kedua adalah pemberantasan kemiskinan dan kelaparan melalui program bantuan sosial. Kelompok ketiga fokus pada pemberantasan kemiskinan dan kelaparan dalam hal ekonomi. Pemerintah menggunakan indikator oleh UNDP sebagai dasar proses pengambilan keputusan, namun juga menggunakan kondisi riil orang miskin di Indonesia sebagai pertimbangan utama.
\end{abstract}

Kata Kunci: Millenium Development Goals, Kemiskinan dan Kelaparan Ekstrim

\section{Introduction}

Indonesia is a developing country which has a vast region and one of the most populated states. As an archipelago country, Indonesia consisted of thousand islands, and each island is separated by the sea. This condition caused the development gap among islands and gave the impact on the rate of poverty and hunger. Considering this characteristic, Indonesia is susceptible to the phenomenon of extreme poverty and hunger. 


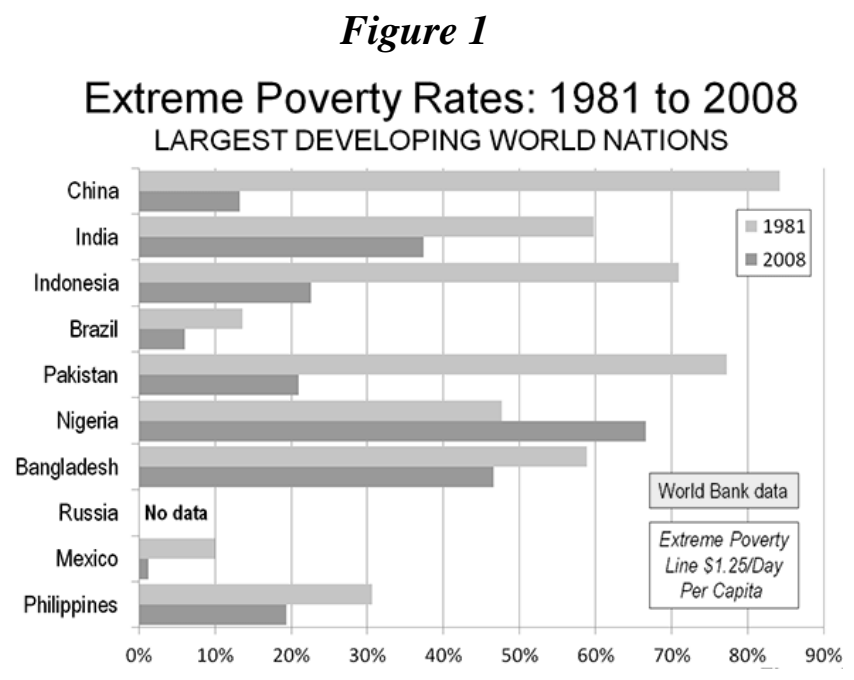

Source:http://www.newgeography.com/content/0 03325-alleviating-world-poverty-aprogress-

A condition of extreme poverty and hunger is the economic and social condition of the people who live under limited access for human needs, especially for food. Based on the United Nations (UN) definition, international extreme poverty and hunger are people whose income less than $\$ 1$ a day. While in 2008, World Bank redefined the standard of extreme poverty and hunger which is those whose income less than $\$ 1.25$ a day. ${ }^{1}$ This change is caused by the fact that the level and standard of needs are increasing.

Extreme poverty and hunger occurred when there is a gap between the ability to afford needs and the actual number of people's demand. Extreme poverty and hunger is a severe problem for the existence of human life because for an extended period it will bring under-nutrition problem.

\footnotetext{
${ }^{1}$ The World Bank (2012, February 29). Retrieved from http://www.worldbank.org/en/news/pressrelease/2012/02/29/world-bank-sees-progress-againstextreme-poverty-but-flags-vulnerabilities.
}

The developing country is a region which has a significant number of people who lived in extreme poverty and hunger, as most states could not provide welfare benefits for its citizen to fulfil their basic needs.

Figure 1 shows the data of Extreme Poverty Rate between 1981 and 2008 in some largest developing countries, which are, China, India, Indonesia, Brazil, Pakistan, Nigeria, Bangladesh, Russia, Mexico, and the Philippines. Extreme poverty in some selected countries was decreasing between 1981 and 2008 and potentially affected by the implementation of Millennium Development Goals (MDGs), considering it focuses on the development of developing states. MDGs was signed by 189 member country of the UN in September 2000 and accomplished in 2015. MDGs has eight programs, which are, Eradicating Extreme Poverty and Hunger, Achieving Universal Primary Education, Promoting Gender Equality and Empower Women, Reducing Child Mortality, Improving Maternal Health, Combat HIV and AIDS, Malaria and other diseases, 
77 Syifa Zia Rahmah, Grace Lestariana Wonoadi dan Achmad Zulfikar | The Implementation of MDGs Program on Eradication of Extreme Poverty and Hunger in Indonesia (2009-2014)

Ensuring Environmental Sustainability, and Developing Global Partnership for Development.

Eradicating extreme poverty and hunger becomes the first point of the MDGs program because that discussion is related to the primary needs of human life and its central theme is ending the poverty. It means the eight programs were developed to achieve the poverty reduction in some aspects not only economy however also education, health, women rights and environment. This research discusses the poverty and hunger phenomenon in Indonesia. More specifically it focuses on the eradication of extreme poverty and hunger under President Susilo Bambang Yudhoyono Administration (2009-2014). Considering 2015 is the last period of the implementation of MDGs. Thus, its final achievements will be directly influenced by how it had been worked between 2009 and 2014 .
This following graphic describes the number and percentage of Indonesian people who lived under poor condition. The number of Indonesian people which is attached to the graphics written is in a million digit. The data which is provided on this graphic was gathered from 1996 until the latest is September 2012. Referring to Figure $2,{ }^{2}$ we can see the poverty and hunger number in Indonesia from 1996 to 2012. The graphic has dynamic movement year by year, but since 2007-2012 the poverty and hunger in Indonesia were decreasing consistently. Since the first administration of President Susilo Bambang Yudhoyono, the program on eradication of extreme poverty and hunger had been provided. Further, in his second presidency, the program had been evaluated yet sustain and more accordance with the MDGs plans.

\section{Figure 2}

The rate of extreme poverty and hunger in Indonesia 1996-2012

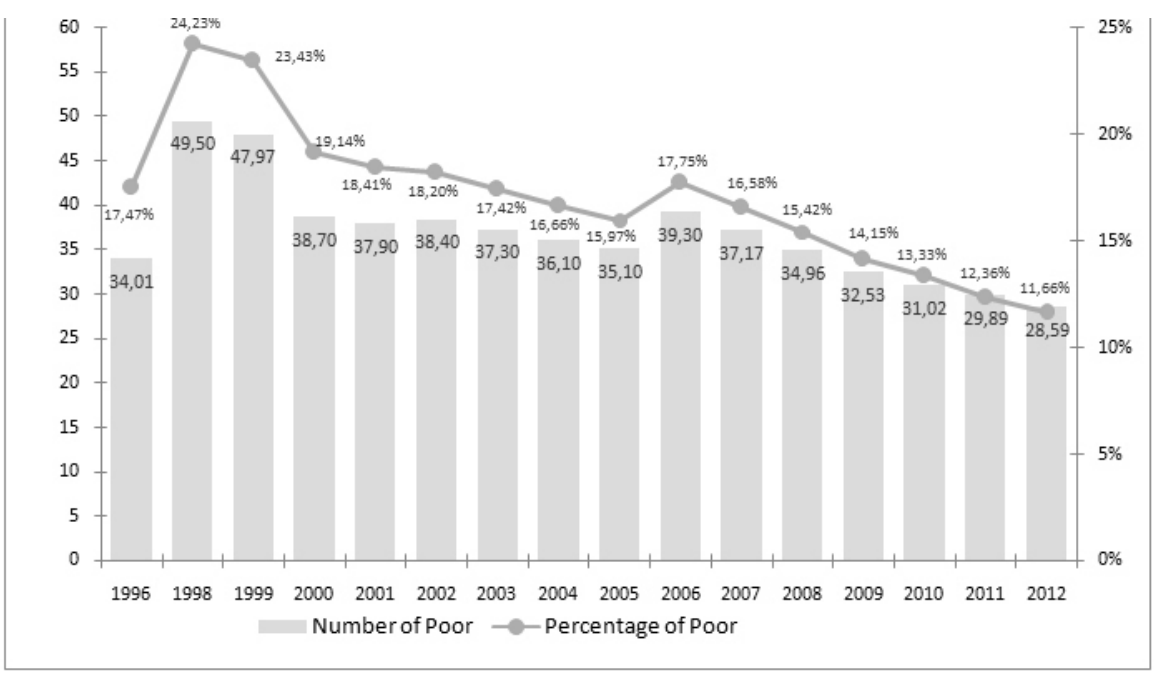

Source:http://www.setneg.go.id/index.php?option=com_content\&task=view\&id=6804

\footnotetext{
${ }^{2}$ Kementrian Sekretariat Negara Republik Indonesia (n.d.). Poverty in Indonesia. Received from https://www.setneg.go.id/index.php?option=com_con tent\&task=view\&id=6804.
} 
78 Syifa Zia Rahmah, Grace Lestariana Wonoadi dan Achmad Zulfikar | The Implementation of MDGs Program on Eradication of Extreme Poverty and Hunger in Indonesia (2009-2014)

which is provided on the table, we can see the decreasing of poverty and hunger numbers in Indonesia during the period 2009-

\section{Figure 3}

The spread of poverty in Indonesia1996-2012

\begin{tabular}{|c|c|c|c|c|c|c|c|c|}
\hline \multirow{2}{*}{ Year } & \multicolumn{3}{|c|}{ The Number of Poor People } & \multicolumn{3}{c|}{$\begin{array}{c}\text { Percentage of Poor People } \\
\text { (on million digit) of total population) }\end{array}$} \\
\cline { 2 - 9 } & Urban & Rural & Total & Difference & Urban & Rural & Total & Difference \\
\hline 1996 & 9,42 & 24,59 & 34,01 & - & $13,39 \%$ & $19,78 \%$ & $17,47 \%$ & - \\
\hline 1998 & 17,60 & 31,90 & 49,50 & 15,49 & $21,92 \%$ & $25,72 \%$ & $24,23 \%$ & $6,76 \%$ \\
\hline 1999 & 15,64 & 32,33 & 47,97 & $-1,53$ & $19,41 \%$ & $26,03 \%$ & $23,43 \%$ & $-0,80 \%$ \\
\hline 2000 & 12,30 & 26,40 & 38,70 & $-9,27$ & $14,60 \%$ & $22,38 \%$ & $19,14 \%$ & $-4,29 \%$ \\
\hline 2001 & 8,60 & 29,30 & 37,90 & $-0,80$ & $9,76 \%$ & $24,84 \%$ & $18,41 \%$ & $-0,73 \%$ \\
\hline 2002 & 13,30 & 25,10 & 38,40 & 0,50 & $14,46 \%$ & $21,10 \%$ & $18,20 \%$ & $-0,21 \%$ \\
\hline 2003 & 12,20 & 25,10 & 37,30 & $-1,10$ & $13,57 \%$ & $20,23 \%$ & $17,42 \%$ & $-0,78 \%$ \\
\hline 2004 & 11,40 & 24,70 & 36,10 & $-1,20$ & $12,52 \%$ & $20,11 \%$ & $16,66 \%$ & $-0,76 \%$ \\
\hline 2005 & 12,40 & 22,70 & 35,10 & $-1,00$ & $11,68 \%$ & $19,98 \%$ & $15,97 \%$ & $-0,69 \%$ \\
\hline 2006 & 14,49 & 24,81 & 39,30 & 4,20 & $13,47 \%$ & $21,81 \%$ & $17,75 \%$ & $1,78 \%$ \\
\hline 2007 & 13,56 & 23,61 & 37,17 & $-2,13$ & $12,52 \%$ & $20,37 \%$ & $16,58 \%$ & $-1,17 \%$ \\
\hline 2008 & 12,77 & 22,19 & 34,96 & $-2,21$ & $11,65 \%$ & $18,93 \%$ & $15,42 \%$ & $-1,16 \%$ \\
\hline 2009 & 11,91 & 20,62 & 32,53 & $-2,43$ & $10,72 \%$ & $17,35 \%$ & $14,15 \%$ & $-1,27 \%$ \\
\hline 2010 & 11,10 & 19,92 & 31,02 & $-1,51$ & $9,87 \%$ & $16,56 \%$ & $13,33 \%$ & $-0,82 \%$ \\
\hline 2011 & 10,95 & 18,94 & 29,89 & $-1,13$ & $9,09 \%$ & $15,59 \%$ & $12,36 \%$ & $-0,97 \%$ \\
\hline $2012 *$ & 10,51 & 18,08 & 28,59 & $-1,30$ & $8,60 \%$ & $14,70 \%$ & $11,66 \%$ & $-0,70 \%$ \\
\hline
\end{tabular}

Source:http://www.setneg.go.id/index.php?option=com_content\&task=view\&id=6804

This Figure $3^{3}$ describes the spread of Indonesian people who lived under the poor condition and the change of poverty number in Indonesia from 1996 until September 2012 (the latest data). Figure 3 divided the data of poor people in Indonesia during 1996-2012 (September) into two categories, which are, the number of poor people in a million digit and the percentage of poor people. Each group consisted of urban and rural data of poor people. Based on the data

${ }^{3}$ Ibid.
September 2012. That data shows that along the period of 2009-2012 or a half time of the 20092014 program, the eradication of extreme poverty and hunger which was a part of MDGs program was getting closer to the MDGs accomplishment in 2015.

Eradication is the way to solve the problem by renewing the old system. Extreme Poverty is the condition of poverty which in the danger zone and the lack of economy causes it. Hunger is the condition of people who cannot afford or gain 
their needs, especially the needs of food as their primary needs. President Susilo Bambang Yudhoyono was the President of the Republic of Indonesia, who led for two periods, 2004-2009 and 2009-2014.

For his second administration in 20092014, President Susilo Bambang Yudhoyono Administration reorganised the programs of eradicating extreme poverty and hunger problem according to the evaluation toward the previous plans and considering the target of MDGs itself. The latter program was divided into three classes or called as a cluster:

The first cluster aims to help and protects the social family guarantee and to assure the basic needs. The programs which covered in the first cluster were: BerasMiskin or Raskin, Jaminan Kesehatan Masyarakat or Jamkesmas, Program Keluarga Harapan (PKH), Bantuan Operasional Sekolah (BOS), and Bantuan Siswa Miskin (BSM).

The second cluster is the eradication of poverty and hunger through the social assistance program or called PNPM Mandiri. This cluster is the path which assisted the social environment to become independent.

The third cluster was focusing on eradication of poverty and hunger in term of economic matter, the programs are, Usaha Ekonomi Mikro and Kecil (UMK) and Program Kredit Usaha Rakyat (KUR).

The three clusters which were implemented by President Susilo Bambang Yudhoyono in his second administration period (2009-2014) was the program of extreme poverty and hunger eradication which was implemented in his first period (2004-2009). However, there were some improvements and difference terms in specific programs needed to be done because of the poor people condition in Indonesia in which was also changed. In the previous period, President Susilo Bambang Yudhoyono administration only released some programs of extreme poverty and hunger eradication without any particular mechanism. Meanwhile, in 2009-2014 periods, President Susilo Bambang Yudhoyono administration released the program in a particular arrangement based on the evaluation in the previous period. Besides, improvement based on the previous program, in 2009-2014, President Susilo Bambang Yudhoyono also released a new plan as an addition. Based on the changes, the writer concludes that there are some differences between the eradication program of extreme poverty and hunger in 2004-2009 and 2009-2014.

In this paper, the writer focuses on the background and significance of the program in term extreme poverty and hunger eradication released by President Susilo Bambang Yudhoyono administration in 2009-2014. The purpose of the research to find out why did Susilo Bambang Yudhoyono Administration revise the program of eradication extreme poverty and hunger became three clusters as the implementation of MDGs in Indonesia?.

\section{Methodology}

This paper used a qualitative approach to collect and complete the data. The data is secondary sources, namely, the official reports, literature and news articles which are relevant toward the issue of implementation of MDGs in Indonesia, focusing on the eradication of extreme poverty and hunger under the President Susilo Bambang Yudhoyono Administration in 2009-2014.

\section{Analysis}

\section{What is Millenium Development Goals?}

Eight points of MDGs program have each detail point that explains clearly what the program is and how the program will be driven. Here, they are the points:

The first point is eradicating extreme poverty and hunger. It has three explanations, which are; halving, between 1990 and 2015, the 
proportion of people whose income is less than $\$ 1$ a day; achieving full and productive employment and decent work for all, including women and young people; and halving, between 1990-2015, the proportion who suffer from hunger. ${ }^{4}$

The second point is achieving universal primary education. The goal of this point is to ensure that, by 2015 , children everywhere, boys and girls, will be able to complete a full course of primary schooling. ${ }^{5}$

The third point is promoting gender equality and empower women, it has a goal to eliminate gender disparity in primary and secondary education, preferably by 2005 , and in all levels of education, no later than 2015 . $^{6}$

The fourth point is reducing child mortality. It means to reduce by two-thirds, between 1990 and 2015, the mortality rate of children under five. ${ }^{7}$

The fifth point is improving maternal health. There are two goals of this point, which are; reducing by three-quarters, between 1990 and 2015, the maternal mortality ratio; and achieving, by 2015, universal access to reproductive health. ${ }^{8}$

${ }^{4}$ United Nations ( n.d.). "Goal 1 Eradicate Extreme Poverty and Hunger.". Retrieved from http://www.un.org/millenniumgoals/pdf/Goal_1_fs.pd $\mathrm{f}$

${ }^{5}$ United Nations ( n.d.). Goal 2 Achieve Universal Primary Education. Retrieved from http://www.un.org/millenniumgoals/pdf/Goal_2_fs.pd f.

${ }^{6}$ United Nations ( n.d.). Goal 3 Promote Gender Equality and Empower Women. Retrieved from http://www.un.org/millenniumgoals/pdf/Goal_3_fs.pd f.

${ }^{7}$ United Nations ( n.d.). Goal 4 Reduce Child Mortality. Retrieved from http://www.un.org/millenniumgoals/pdf/Goal_4_fs.pd f.

${ }^{8}$ United Nations ( n.d.). Goal 5 Improve Maternal Health. Retrieved from http://www.un.org/millenniumgoals/pdf/Goal_5_fs.pd f.
The sixth point is to combat HIV and AIDS, Malaria and other diseases, it has three goals, which are; halting and beginning to reverse, by 2015, the spread of HIV/AIDS; achieving universal access to treatment for HIV/AIDS for all those who need it; and halting and beginning to reverse, by 2015 , the incidence of malaria and other major disease. ${ }^{9}$

The seventh point is ensuring environmental sustainability. It consists of four goals, which are; integrating the principles of sustainable development into country policies and programs and reverse the loss of environmental resources; reducing biodiversity loss, achieving, by 2010, a significant reduction in the rate of loss; halving, by 2015, the proportion of the population without sustainable access to safe drinking water and basic sanitation; and achieving, by 2020, a significant improvement in the lives of at least 100 million slum and dwellers. ${ }^{10}$

The eighth point is developing a global partnership for development. It is explained by five goals, which are; developing further an open, rules-based, predictable, non-discriminatory trading and financial system; addressing the special needs of least developed countries, landlocked countries and small island developing states; dealing comprehensively with developing countries debt; cooperating with pharmaceutical companies, providing access to affordable, essential drugs in developing countries; and cooperating with the private sector, making

\footnotetext{
${ }^{9}$ United Nations ( n.d.). Goal 6 Combat HIV/AIDS, Malaria and Other Diseases. Retrieved from http://www.un.org/millenniumgoals/pdf/Goal_6_fs.pd f.

${ }^{10}$ United Nations ( n.d.). Goal 7 Ensure

Environmental Sustainability. Retrieved from http://www.un.org/millenniumgoals/pdf/Goal_7_fs.pd f.
} 
81 Syifa Zia Rahmah, Grace Lestariana Wonoadi dan Achmad Zulfikar | The Implementation of MDGs Program on Eradication of Extreme Poverty and Hunger in Indonesia (2009-2014)

available benefits of new technologies, especially ICTs. ${ }^{11}$

\section{MDGs Program on Eradication of Extreme Poverty and Hunger in Indonesia from 2000 to 2014}

In the aftermath of the Indonesian reformation, the government expected to overcome the consequence of financial crisis which led to the highest inflation and eventually considerable people were entering the poverty condition. Therefore, the government agreed to comply MDGs which its main theme is to end poverty. A program which set series indicators needed by Indonesia.

In its implementation, MDGs which initiated by the UN not necessarily should be driven according to the UN ways, instead UNDP, as the presentation of the UN for charging MDGs, gives no force majeure for each country in term of MDGs program implementation. There is no sanction or punishment will be given toward the country which failed to reach the goal of MDGs. However, even there is punishment for the failure of MDGs implementation, the government of the Republic of Indonesia gives the best effort to reach the goals of the MDGs program as much as possible. The main consideration for the government is MDGs program offers a chance, especially for the developing countries to be free from poverty in the whole aspects of human life, as likes the theme of MDGs which is End Poverty in 2015.

In this part, the writer explains the eradication program of extreme poverty and hunger in Indonesia during 2000-2014. As the MDGs started in 2000 and the last period of the second administration of President SusiloBambangYudhoyono ended in 2014, thus

\footnotetext{
${ }^{11}$ United Nations ( n.d.). Goal 8 Develop a Global Partnership for Development . Retrieved from http://www.un.org/millenniumgoals/pdf/Goal_8_fs.pd f.
}

the writer considered these periods are essential to provide a comprehensive background.

During 2000-2014 Indonesia was led by some presidents. They were, KH Abdurrahman Wahid (1999-2001), Megawati Soekarno Putri (2001-2004), and Susilo Bambang Yudhoyono for two periods 2004-2009 and 2009-2014. Each president had their consideration which influenced the decision-making process of certain programs, including the eradication program of extreme poverty and hunger. Although there were difference considerations used in the decision-making process, the plans were released based on the target which was determined in the MDGs program. The explanation of this part is divided into two sections, which are, the eradication program of extreme poverty and hunger did in pre-President Susilo Bambang Yudhoyono Administration period (2000-2004) and eradication program of extreme poverty and hunger did in the era of President Susilo Bambang Yudhoyono Administration period (2004-2014).

During 2000-2004 Indonesia was led by two presidents. In 2000, under President $\mathrm{KH}$ Abdurrahman Wahid Administration, the government released the National Development Program or simply called PROPENAS 20002004. However in the middle of 2001, during President KH Abdurrahman Wahid administration there was coup d'etat done by parliament, and it caused the Vice President Megawati Soekarno Putri took the responsibility as the President of Republic of Indonesia. Since the National Development Program had been signed for 2000-2004, President Megawati Soekarno Putri administration created eradicating extreme poverty and hunger program in Indonesia based on the previous program.

In 2000, under the administration of President KH Abdurrahman Wahid, the program of eradication extreme poverty and hunger focused on two aspects, which were, a program of basic need fulfilment for poor people and 
program of poor people empowerment. Those two programs had been decided based on some considerations in 2000. It was the transition period for Indonesia in terms of state system after dealing with the case of the monetary crisis in 1998. The program of basic need fulfilment for poor people became the priority to avoid the increase of poverty number in Indonesia. Since the monetary crisis in 1998 , Indonesia has been dealing with economic problems which potentially increase the number of poverty in Indonesia.

The program of basic needs fulfilment for poor people covered up providing foodstuff, health and education facilities, and housing repairment program. Providing foodstuff program is a program in which the government gave rice for poor people. It is called as Raskin which was given for poor people who were noted on the database. This program is important to minimise the threat of hunger problem. Health and education facilities become part of basic need fulfilment since both matters influence the poverty rate. Health facility was given in the program called Jamkesmas or social health warranty. Meanwhile, the education facility was given in the program of 9 years period of study obligatory. This program aims to create a better quality of Indonesian people by having a better job and earning a bigger salary. The housing repairment program was one of basic need program of government in order to give a better environment. For poor people, in this issue, the government paid attention to clean water availability because most poor people lacked clean water availability.

The second aspect in the matter of poor people empowerment, the government had set a program named UMKM. The program aimed at a media or tool for micro, small, intermediate, and cooperative in developing their business. This program was given in the form of workshop and assistance to eradicate poverty based on their own work.

\section{Eradication of Extreme Poverty and Hunger in 2009-2014 from Public Policy Perspective}

The eradication program of extreme poverty and hunger for the period 2009-2014 has the background in which can be explained using the public policy concept.

The main idea of public policy concept is to connect the role among the government as the decision maker, society as the object of the policy or program, and international organisation as the third party. In this case, the government of the Republic of IndonesiaI used the needs of poor people in which becomes the object as the main consideration of the eradication program of extreme poverty and hunger.

The factor of extreme poverty and hunger in Indonesia is about the growth of population in which not followed by the capability to fulfil the basic needs and the limited job available. Those factors lead to the problem of poverty and hunger worse. Based on this condition, the government under President Susilo Bambang Yudhoyono released the eradication program of extreme poverty and hunger for 2009-2014 in which fulfil the need of poor people. Initially, in his first administration, the eradication of poverty had been managed into a program called the National Strategy for Poverty Reduction. Its main objections were to eliminate the gap among regions, provide job opportunity, and fulfil the basic rights of poor people as mandated by the 1945 Constitution.

As the additional consideration, the government has also used the target in which had been determined by UNDP as the stakeholder of MDGs program as the indicator. In the issue of eradicating extreme poverty and hunger, there are three targets used as the indicator, which is, halving the number of people whose income less $\$ 1$ a day, maximizing the productive employment participation especially for women and young people, and the last one is halving the number of people who suffer from hunger. 
Both the needs of poor people in Indonesia and the target of MDGs were formulated into some programs of eradicating extreme poverty and hunger. Those programs are arranged based on the priority, and structured becomes three clusters. Each cluster determined based on the indicator of MDGs in the issue of eradicating extreme poverty and hunger, and each cluster has different accomplishment.

In the indicator of poverty issue in Indonesia, the government of the Republic of Indonesia has been success reduce the poverty rate between the periods of 2009-2014, which were, $14.15 \%$ become $10.96 \%$. Even the number of poverty which had been reduced called as significant from 32.53 million people becomes 27.33 million people. However, it did not fulfill the target had been declared in MDGs program. It caused by the government of the Republic of Indonesia up to 2014 cannot reduce becomes a half of poverty rate based on the data in 1990, which was, $15.1 \%$. However, the government has not failed yet, because the final accomplishment was in 2015 , means there was one year left.

In the indicator of productive employment participation, the program of PNPM Mandiri was considerate as the susceptible program with the condition of unemployment, especially for women and young people in Indonesia. The decision taken by the government to release the PNPM Mandiri has been fulfilled the target of the MDGs program. Based on the data of productive employment participation in 1990 was only 73.10 million people and in the last period of President Susilo Bambang Yudhoyono administration in 2014, the productive employment participation increased significantly becomes 114.6 million people. This accomplishment gives the good sign for the fullachievement had been targeted in MDGs program.

In the indicator of the hunger issue in Indonesia, the government of the Republic of
Indonesia up to 2014 got the fact that the hunger problem was increasing, instead of decreasing. This kind of problem caused by the increase of population whose cannot afford the consumption of $1400 \mathrm{kcal} /$ day. The data of hunger in Indonesia in 1990 was only $17 \%$, while in 2014 it was $17.39 \%$. It was not a significant increase, but it caused the government has to work harder to maximise the accomplishment in 2015.

\section{The Significant of Program on Eradication of Extreme Poverty and Hunger in 2009-2014}

The government under President Susilo Bambang Yudhoyono administration has been released three clusters to implement the MDGs program in the issue of eradicating extreme poverty and hunger. These three clusters are; First Cluster, this cluster is purposed to help and protect the social family guarantee, it is to assure the basic needs of poor people. The program which covered in this cluster are: Rice for the Poor (Beras Miskin) or known as Raskin, Community Health Insurance (Jaminan Kesehatan Masyarakat) or known as Jamkesmas, Hope for the Family Programme (Program Keluarga Harapan/PKH), School Operational Assistance (Bantuan Operasional Sekolah/BOS), and Scholarship for Poor Student (Bantuan Siswa Miskin/BSM). The second Cluster, this cluster is purposed to eradicate extreme poverty and hunger through social assistance program or called PNPM Mandiri. In this cluster, the government try to help the poor people by assisting and make them becomes independent people. The third cluster, this cluster is focusing on eradication of extreme poverty and hunger in term of economic matter, the government prepared the program named Micro and Small Economic Enterprises (Usaha Ekonomi Mikro dan Kecil/UMK) and Credit for Society (Kredit Usaha Rakyat/KUR).

President Susilo Bambang Yudhoyono administration for the period 2009-2014 has some considerations in which distinct those 
programs from other programs in the previous period on eradicating extreme poverty and hunger issue. The consideration had by the government can be explained using rational choice model and the concept of public policy. The rational choice model explains four steps in sequence in which have to follow by the government to choose the best decision based on the comparison between advantage and disadvantage.

According to the rational choice model, to implement the MDGs program in the issue of eradicating extreme poverty and hunger, the Indonesian government has to determine their general goal. The determination process of the general goal named goal clarify as the first step in the rational choice model. The general goal had by the government in which will be synchronised toward the indicator determined by UNDP in the next step. While, in this step the government under President Susilo Bambang Yudhoyono in 2009-2014 has been set the goals, which are, reduce the number of people who lived in the poverty condition, increase the number of prosperity, and facilitate the participation in the economic matter, especially for women and young people.

Indonesia is one of the developing, and most populated countries close with the problem of poverty. Therefore, the government has to put serious attention to implement the MDGs program which was signed in 2000.

The second step in the issue of eradicates extreme poverty and hunger, the government of the Republic of Indonesia in 2009-2014 followed the indicator determined by UNDP as the part of the implementation of MDGs program (Mustopadidjaja, 2012, p. 370). There are three indicators had been signed by UNDP, which are, halve, between 1990 and 2015 , the proportion of people whose income is less than \$1 a day; achieve full and productive employment and decent work for all, including women and young people; and halve, between
1990-2015, the proportion who suffer from hunger. ${ }^{12}$

Based on these indicators the government divided the issue of extreme poverty and hunger becomes three aspects, which are, poverty, productive employment participation, and hunger. In the aspect of poverty, the government has to reduce the number of poverty in 1990 which is 27.2 million people $(15.1 \%)^{13}$ becomes at least $8 \%$ in $2014^{14}$. As mentioned before that due date of MDGs is on 2015 and regarding the indicator which determining that each country who has been signed the MDGs program has to use those indicators as the base in the eradication of extreme poverty and hunger.

In the aspect of productive employment participation, the government has to provide a larger field of job in which can facilitate the employment to get freed from the problem of unemployment. The number of population year by year always increased, and it caused the number of productive employment was also increase. To avoid the problem of unemployment, the government has to put severe attention in term of provides the available job. In the aspect of hunger, the government has to makes a program in which can reduce the number of hunger becomes $8.5 \%$ in 2014. $8.5 \%$ is the target in which determined based on the number of hunger in 1990 which is $17 \%$.

The third step is to identify alternatives that might be chosen as the solution to reach the goals. Based on the indicator which has been signed by UNDP and would to be implemented

\footnotetext{
12 United Nations (2015, April 14). Millenium Development Goals. Retrieved from www.un.org/millenniumgoals/pdf/Goal_1_fs.pdf

${ }^{13}$ Badan Pusat Statistika (2016, January 16). Jumlah Penduduk Miskin, Persentase Penduduk Miskin, dan Garis Kemiskinan 1970-2013. Retrieved from http://www.bps.go.id/linkTabelStatis/view/id/1494 14 AR Mustopadidjaja, BAPPENAS dalam Sejarah Perencanaan Pembangunan Indonesia 1945-2025 (pp. 389). Jakarta: LP3ES. 2012
} 
in term of eradicating extreme poverty and hunger, the government of the Republic of Indonesia set some programs as the alternative. In this step, the programs were set by the government are the general one, means the following and detail program will be included in the last step. The general alternative which determined in this step becomes the framework for the following step. Some programs in which set by the government are school insurance, health insurance, social assistance, and economic assistance.

The final step in the rational choice model is the developing of the alternative which will be implemented in term of eradicating extreme poverty and hunger in Indonesia under President Susilo Bambang Yudhoyono administration for 2009-2014. As mentioned before that the government has released three clusters in which fulfil each indicator in the issue of eradicate extreme poverty and hunger. In terms of reducing the proportion of people whose income is less than $\$ 1$ a day mainly between 1990 and 2015, the government released the two programs named UMK as the acronym of Unit Ekonomi Mikro dan Kecil and KUR as the acronym of Kredit Usaha Rakyat. Both programs are included the third cluster in which has the goal to eradicate extreme poverty and hunger in the economic matter. Those two programs are seen relevance to increase the income of people who have less than $\$ 1$ a day. For the program of UMK, it was implemented since President Abdurrahmahman Wahid administration. The consideration used by the President Susilo Bambang Yudhoyono administration was still implementing this kind of program for the period 2009-2014 is this program gives a chance for poor people to be freed from their problem through the economic assistance by the government.

Based on the report of poverty rate in which counted the amount of people whose income is less than \$1 a day, since 2000-2008 there was a good record in which indicate the significant decreasing, even in certain period, such as, 2006 there was an increase of poverty caused by the revocation of gasoline subsidy. While the KUR program is known as the new one for the eradication of extreme poverty and hunger in Indonesia. This kind of program was seen as the important one to support the achievement. The program of KUR was purposed to be a complement of UMK. The UMK is the program was used to facilitate the poor people drive their business in various sectors. While the program of KUR is the system in which give easy way to get the financial supported.

For the second indicator which achieves full and productive employment and decent work for all, including women and young, the government released the program named National Program for Independent Community Empowerment (Program Nasional Pemberdayaan Masyarakat Mandiri) or known as PNPM Mandiri. This kind of program was provided to facilitate productive employment, especially women and young people who has no job because there is a limited available field of job. Unemployment becomes one of the caused in the poverty problem. Some factors can trigger the issue of unemployment itself, for instance, the limited available field of job and the limited of skill. Therefore, to cut off those two factors of unemployment, the government makes PNPM Mandiri. This kind of program gives a chance to the productive employment in which has no job to create their job or to increase their skill in which can fulfil the requirement determined by the institution where looking for full-skill employment. This program is entirely different from UMK and KUR in which the government used economic approach. While, to drive PNPM Mandiri, the government used social approach. The government gives no cash for supporting their business, instead of gives the workshop and seminar about the skill improvement which is 
needed in term of creating the field of job or looking for the job vacancy.

The last indicator is to reduce by fifty percent, between 1990-2015, the proportion who suffer from hunger. To reach this indicator, the government has been adopted some programs to be implemented in the eradication of extreme poverty and hunger, which are, BOS, Jamkesmas, Raskin, BSM, and PKH. If in the two previous clusters, the government has only focused on using certain matter, while in this cluster, the government focus on some issues, such as education, health, and economic. The first three programs have been implemented since the previous period and based on the report about those programs are indicate a good result. It makes the government under President Susilo Bambang Yudhoyono administration counted as the consideration in which can fulfil the indicator which has been determined by UNDP, while the last two programs were a new program. BSM is a program for the student who comes from a poor family. This program was different with BOS in which the government had determined gives for all students in every level of study. BSM was purposed to fulfil the need of school equipments, such as book, uniform, and other related things. The last program of extreme poverty and hunger eradication is $\mathrm{PKH}$. This kind of program was given for family whose fulfill the condition determined by the government, which are, family which has child whose age 0-6 years old and family which has the child under the age of school obligatory. The government gives the money in cash to help the impoverished family in term of needs fulfilment.

The arrangement of three clusters, namely, social family aids, social assistance program, and economic assistance, makes it different from other programs in the previous period. Although, there is some similar kind of program, still, there is an improvement for those programs which makes the effort to accomplish eradicate extreme poverty and hunger become faster and effective.

\section{Conclusion}

The programs of eradication extreme poverty and hunger in 2009-2014 had been revised became three clusters by President Susilo Bambang Yudhoyono administration because they were susceptible with either the needs of poor people in Indonesia or the indicator of MDGs itself. The government used the three indicators had been determined by UN in which represented by UNDP, as the base of decisionmaking process. But, the government was also used the real condition of poor people in Indonesia as the main consideration. Therefore, the decision which taken during the period 20092014 was considerate those two matters.

The government under President Susilo Bambang Yudhoyono administration released the eradication program of extreme poverty and hunger were consists of three clusters to make program is structured and organised. Those clusters of the eradication program in the issue of extreme poverty and hunger are chosen as the way of the government of Indonesia to implementing the MDGs program. By implementing the MDGs program, the government of Indonesia was showing active participation as the member of $\mathrm{UN}$ and following the international order in term of end the poverty.

\section{References}

2012. The World Bank. February 29. Accessed December 21, 2018. http://www.worldbank.org/en/news/pres s-release/2012/02/29/world-bank-seesprogress-against-extreme-poverty-butflags-vulnerabilities.

AR, Mustopadidjaja. 2012. BAPPENAS dalam Sejarah Perencanaan Pembangunan Indonesia 1945-2025. Jakarta: LP3ES. 
87 Syifa Zia Rahmah, Grace Lestariana Wonoadi dan Achmad Zulfikar | The Implementation of MDGs Program on Eradication of Extreme Poverty and Hunger in Indonesia (2009-2014)

Bappenas. 2011. Laporan Pencapaian Tujuan

Pembangunan Millenium di Indonesia

2010. Jakarta: Kementrian Perencanaan

Pembangunan Nasional.

Bappenas. 2012. Laporan Pencapaian Tujuan Pembangunan Millenium Di Indonesia 2011. Jakarta: Kementrian Perencanaan Pembangunan Nasional.

Bappenas. 2014. Laporan Pencapaian Tujuan Pembangunan Millenium Di Indonesia 2013. Jakarta: Kementrian Perencanaan Pembangunan Nasional.

Bappenas. 2015. Laporan Pencapaian Tujuan Pembangunan Millenium Di Indonesia 2014. Jakarta: Kementrian Perencanaan Pembangunan Nasional.

J, Ravenhill. 2005. Global Political Economy. New York: Oxford University Press.

Kegley, Charles K, and Eugene R Wittkopf. 2001. World Politics Trends and Transformation. Belmont CA: Wodsworth Group.

BIBLIOGRAPHY $\backslash 1033$ BIBLIOGRAPHY V 1033 BIBLIOGRAPHY \I 1033 $\begin{array}{lll}\text { BIBLIOGRAPHY } \quad \text { I } & 1033\end{array}$ BIBLIOGRAPHY $\quad$ ll 1033 BIBLIOGRAPHY $\backslash 1 \quad 1033 \quad$ n.d. "Allevating World Poverty a Progress Report." New Geography. Accessed April 28, 2015. http://www.newgeography.com/content/ 003325-alleviating-world-povertyaprogress-report.

n.d. "Goal 1 Eradicate Extreme Poverty and Hunger." United Nation. Accessed April 14 , 2015. http://www.un.org/millenniumgoals/pdf/ Goal_1_fs.pdf.

n.d. "Goal 2 Achieve Universal Primary

Education." United Nation. Accessed April 14, 2015.

http://www.un.org/millenniumgoals/pdf/ Goal_2_fs.pdf.
BIBLIOGRAPHY \l 14345 n.d. "Goal 3

Promote Gender Equality and Empower Women." Accessed April 14, 2015. http://www.un.org/millenniumgoals/pdf/ Goal_3_fs.pdf.

n.d. "Goal 4 Reduce Child Mortality." United Nation. Accessed April 14, 2015. http://www.un.org/millenniumgoals/pdf/ Goal_4_fs.pdf.

n.d. "Goal 5 Improve Maternal Health." United Nations. Accessed April 14, 2015. http://www.un.org/millenniumgoals/pdf/ Goal_5_fs.pdf.

n.d. "Goal 6 Combat HIV/AIDS, Malaria and Other Diseases." United Nation. Accessed April 14, 2015. http://www.un.org/millenniumgoals/pdf/ Goal_6_fs.pdf.

n.d. "Goal 7 Ensure Environmental

Sustainability." Accessed April 14, 2015. http://www.un.org/millenniumgoals/pdf/ Goal_7_fs.pdf.

n.d. "Goal 8 Develop a Global Partnership for Development ." United Nations. Accessed April 14, 2015. http://www.un.org/millenniumgoals/pdf/ Goal_8_fs.pdf.

n.d. "Poverty in Indonesia." Kementrian Sekretariat Negara Republik Indonesia. Accessed April 14, 2015. https://www.setneg.go.id/index.php?opti on=com_content\&task=view\&id=6804.

P, John. 2012. Analyzing Public Policy 2nd Edition. New York: Routledge.

Pusat Pengkajian Pengolahan Data dan Informasi Sekretariat Jendral DPR RI. 2013. "Pencapaian Millenium Development Goals (MDGs) di Indonesia melalui Kerjasama Internasional." Politica Vol. 4 No. 1 129-156.

BIBLIOGRAPHY \l 1033 Redaksi Sinar Grafika. 2001. PROPENAS 2000-2004 
88 Syifa Zia Rahmah, Grace Lestariana Wonoadi dan Achmad Zulfikar | The Implementation of MDGs

Program on Eradication of Extreme Poverty and Hunger in Indonesia (2009-2014)

UU No. 25 Th 2000 Tentang Program

Pembangunan Nasional Tahun 2000-

2004. Jakarta: Sinar Grafika Offset.

World Bank Team. 2007. Era Baru dalam Pengentasan Kemiskinan di Indonesia. Jakarta: World Bank. 